\title{
Metacognitive Awareness Strategies For Listening Comprehension
}

\author{
Ch'ng Looi-Chin \\ Norseha Unin \\ \& \\ Aiza Johari \\ Academy of Language Studies \\ Universiti Teknologi MARA, Sarawak
}

email:looichinchng@gmail.com,norseha@sarawak.uitm.edu.my,aiza@sarawak.uitm.edu.my

\begin{abstract}
Language educators tend to focus extensively on reading and writing skills. Listening activities are often carried out only to test the students' abilities which may lead to their anxiety and apprehension (Vandergrift, 1999). Generally, many students face difficulty in their listening assessments. Students need to apply certain mental steps or operations in listening to encounter their listening problems. These mental steps are referred to as strategies to assist the learners to achieve a reasonable listening comprehension (Goh, 2002).This study is designed to identify the students' levels of Metacognitive Awareness Strategies in performing their listening tasks and to examine the influence of the strategies on their test scores. The study was conducted in two stages of Pre-test and Post-test, where 100 participants were selected based on a convenience sampling. After submitting their Pre and Post-tests, they were required to complete a Metacognitive Awareness Listening Questionnaire (MALQ), developed by Vandergrift et al. (2006). Overall, the findings show an increase in the percentage of correct answers for the listening comprehension task, based on the MCQ given. The findings reveal that metacognitive strategy awareness has a positive effect on students' test scores. ESL teachers can enhance the use of MALQ strategies for listening comprehension. Further research is necessary to study how metacognitive strategies affect the students' listening performance, as well as, to conduct interventions that will encourage metacognitive awareness.
\end{abstract}

Keywords: Listening comprehension, Metacognitive Awareness Strategies, Listening anxiety

\section{INTRODUCTION}

Listening Comprehension is an important component of language learning that requires a great deal of mental activity on the part of the listener (Vandergrift, 1999). It plays a critical role in facilitating language learning as it provides four advantages that include: cognitive, efficiency, utility, and affective advantage (Gary, 1975 as cited in Vandergrift, 1999). Awareness and the use of listening strategies can help students to

*This article is based on a paper presented at the International Conference on the Teaching and Learning of Languages (ICTLL) 2017 organized by the Faculty of Languages and Communication, UPSI. 
learn a highly integrative skill for listening comprehension. However, more often than not, language educators have the tendency to focus on reading and writing skills when teaching English as a Second Language. In some cases, listening activities are often carried out as tests or assessments to evaluate the students' abilities for listening comprehension, which may lead to anxiety and apprehension (Vandergrift, 1999). There are also some other internal and external listening barriers which may impede the students' comprehensions in listening tasks.

Hargie (2011) suggested that such barriers can exist at any stage of listening process: receiving, interpreting, recalling, evaluating and responding to speech. The barriers can be contributed from the aspects of environment, physical, cognitive and personal, bad practices, lack of listening preparations, bad messages from speakers and prejudice. The findings in Chang's (2013) study illustrated that most EFL learners experience listening text issues, the speaker, lacking of motivation and interest, presentation of the spoken text, and factors relating to the students themselves.

Therefore, metacognitive awareness strategies would be useful for students to accomplish their listening tasks and overcome these barriers. Students need to apply certain mental steps or operations in listening to encounter their listening problems. These mental steps are referred to as strategies to assist the learners to achieve a reasonable listening comprehension (Goh, 2002). However, not many learners are aware of how this mental mechanism is functioning and the appropriate coping strategies needed to accomplish the listening tasks especially in ESL (English as a Second Language) classrooms. Without such understanding, students may face limitations in completing their listening tasks and thus, affecting their performances in language learning. In addition, the learners may have limited success in listening due to the challenges in constructing meaning of words. Therefore, a study on listening strategies can be useful for educators to address the problems of listening comprehension. In fact, metacognitive awareness strategies have been used to support and improve students' listening comprehension (Vandergrift, 2002; Vandergrift, et. al. 2006; Selamat \& Sidhu, 2011; and Rahimi \& Katal, 2012). This study is designed to identify the students' levels of Metacognitive Awareness Strategies for performing their listening tasks and to examine the influence of the strategies on their test scores.

\section{METACOGNITIVE AWARENESS STRATEGIES}

Metacognitive awareness strategies can be one of the ways to raise awareness for listening tasks. Metacognition is a process in which the person is actively monitoring, controlling, and arranging the cognitive process in order to attain cognitive goals (Flavell, 1976). Additionally, metacognition can act as a guiding process to learning, in which the learner is using strategies to plan, monitor and evaluate language use and language learning. In fact, metacognitive strategies are essential to succeed in listening comprehension, and these strategies can be taught (Vandergrift, 1999).

Metacognitive strategies involve the three processes of planning, monitoring, and evaluating (Vandergrift, 1999). Firstly, when planning for listening activities, teachers should prepare students for what they will hear and what they are expected to do. As such, students can make predictions to anticipate what they might hear. Subsequently, students who are prepared with selective attention can focus their attention on meaning 
while listening. Secondly, during the actual listening activity, students will monitor their comprehension by interpreting the oral text based on their inferencing abilities. Finally, after the listening activity, a reflection process helps to stimulate the strategy of evaluation. Teachers can encourage reflection by asking the students to assess the effectiveness of the strategies used.

Metacognitive processes like prediction, planning, monitoring, evaluating and problem-solving were utilized by Vandergrift and Tafaghodtari (2010) to an experimental group of 59 French students in which the experimental group successfully outperformed the control group. In recent years, studies by Abdullah Coşkun (2010) on some beginner preparatory school learners at a university in Turkey and by Parviz Birjandi and Amir Hossein Rahimi (2012) on Iranian EFL university students also indicated some encouraging impacts of metacognitive strategy instruction on learners' listening comprehension. In addition, other studies have also shown that students can be taught these strategies to enhance their performance on listening tasks. For example, O'Malley and Chamot (1990) concluded that strategy instruction for academic listening could be effective in enhancing initial learning when teachers pair the learning strategy instruction with listening tasks.

Instruction on strategies can also help students to improve their performance on listening tasks. A study by Thompson and Rubin (1996) on the listening comprehension performance of university students learning Russian, demonstrated that the students who received strategy instruction in listening to audio-recorded texts improved significantly over those who had received no instruction.

\section{METACOGNITIVE AWARENESS LISTENING STRATEGIES}

This study is informed by the following three relevant studies. Firstly, a study on the level of metacognitive listening strategies awareness in learning English for 122 university students and 116 high school students in Iran (Rahimi \& Katal, 2012). The study employed the Metacognitive Awareness Listening Questionnaire (MALQ) (Vandergrift, et al., 2006). It was found that, in general, the high school students were more aware of their metacognitive listening strategies compared to university students. The findings are consistent with the existing literature that students of different age levels with different abilities have significantly different metacognitive listening strategies awareness. While the high school students showed higher awareness in mental translation and person knowledge strategies, the university students were found to use less mental translation strategies. University students have become more aware of the inefficiency of translation strategies and therefore, avoid them.

In a different study to seek a deeper understanding of how pre-university students process a listening task, Nair et. al. (2014) employed a qualitative method of verbal protocol analysis on Malaysian college students. This study utilized a thinkaloud procedure as the main methodology to explore the listening processes, which involved six students from semester two of a diploma program. The findings reveal a wide array of listening processes occurred in the students' verbal reports. During listening, the students were found to evaluate, infer, interpret, predict, and pay selective attention. The findings are useful for teachers to create awareness about the variety of strategies that students use to improve listening comprehension. The integration of 
listening processes and strategies can shift the learners' focus from the product of listening to the array of processes that allow for critical listening.

Additionally, an earlier study by Goh (1997) found that when students become fully aware of their listening processes, they become more autonomous listeners. The ten students in the study were enrolled in an intensive English program at an institute in Singapore. These 19-year-old students were from the People's Republic of China. Using the listening diary as a self-reporting procedure, students were asked to record their observations, reactions, and perceptions of the listening processes. The study was conducted half-way through the six months program. Each student submitted one entry per week and this was done for ten weeks. All in all, forty entries were analyzed for the study. It was reported that the students had a high degree of metacognitive awareness as demonstrated by the listening diaries. According to Goh (1997), the students were capable of observing cognitive processes in their listening because keeping a diary provided them with the right stimulus to reflect on their listening.

In sum, the above three studies (Rahimi \& Katal, 2012; Nair et. al., 2014; Goh, 1997) provide insights on the influence of metacognitive strategies on listening comprehension. The study using Metacognitive Awareness Listening Questionnaire (MALQ) by Vandergrift et al. (2006) provides a way to develop the questionnaire items for this study. While Rahimi and Katal's (2012) study enhances the method to identify the levels of Metacognitive Awareness Strategies and to examine the influence of the strategies on the test scores.

\section{METHODOLOGY}

Figure 1 illustrates the framework for data collection for this study. It was conducted in two stages of Pre-test and Post-test. A total of 100 college students participated in this study. All participants were selected based on a convenience sampling i.e. students who were enrolled in the introductory English classes that were taught by the three researchers. This English course prepares first-year students from various diploma programs for listening comprehension. 


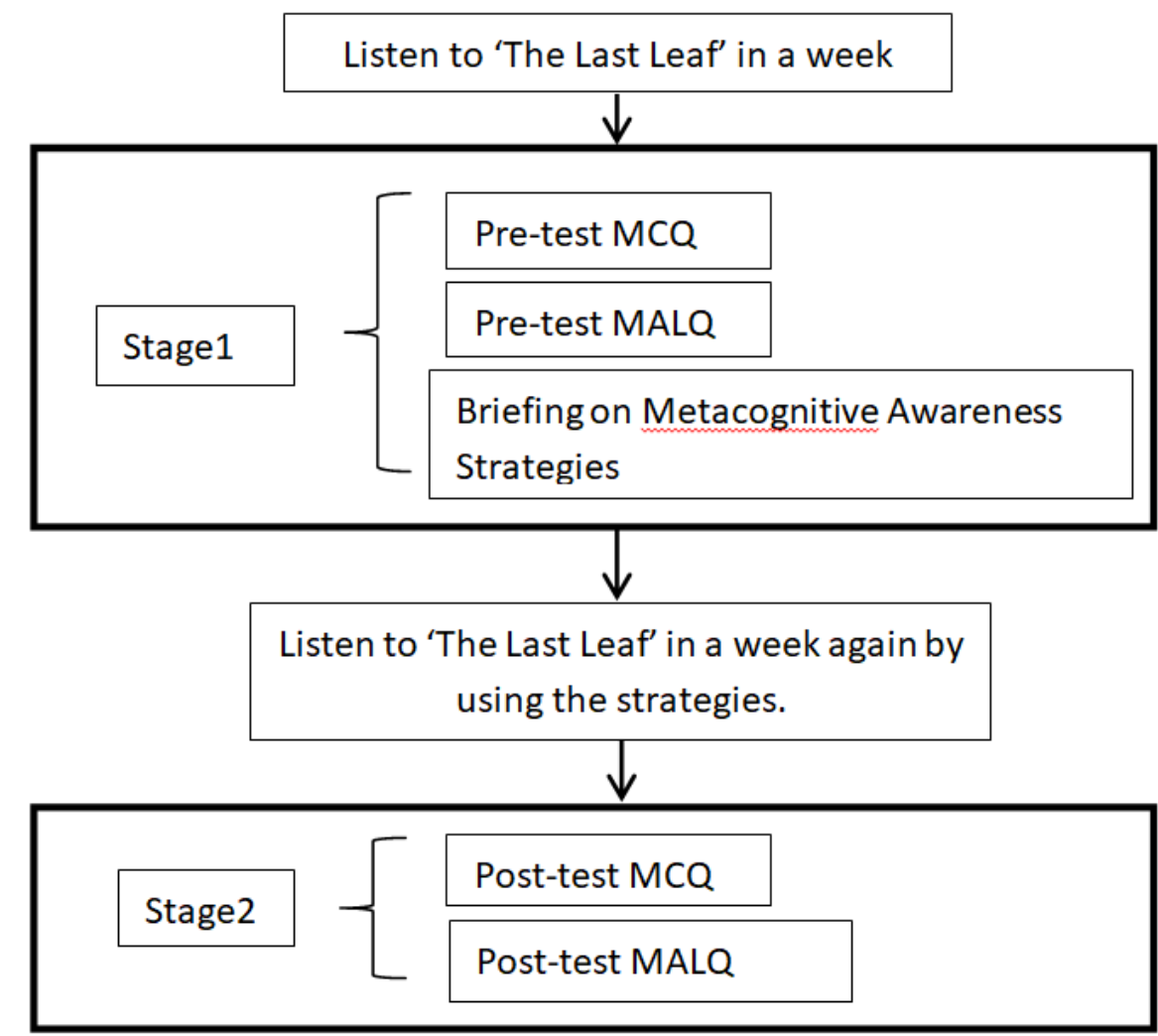

Figure 1: Framework for Data Collection

\section{Pre-Test}

Students were asked to listen to a story entitled The Last Leaf at their own time (within one week). After a week, they were given half an hour in class to complete a set of Pretest questions. The self-designed 20 Multiple Choice Questions (MCQ) were set according to 5 main literature components: Characters, Setting and Plot and Point of Views and Moral Values. The MCQ items were given to 4 lecturers who have taught the same course for 2 semesters to test the validity and reliability of the items.

After students have submitted their Pre-test, they were required to complete a Metacognitive awareness survey. Developed by Vandergrift et al. (2006), this MALQ survey consists of 21 items that consist of five elements: problem-solving (6 items), planning and evaluation ( 5 items), mental translation (3 items), person knowledge (3 items), and directed attention (4 items). This 6-point Likert scale MALQ is conducted to identify the level of metacognitive awareness for listening comprehension and as an exposure for the students to reflect and evaluate themselves upon completing the listening comprehension task. The following week, the students were briefed on the metacognitive awareness strategies and their benefits in improving their listening comprehension.

\section{Post-Test}

Students were asked to listen to the same story at their own time for another week. They were encouraged to analyze the story based on the four literary components from the 
MCQ Pre-test. After a week of Self Learning Time, the students were asked to complete a similar 20 MCQ. The post-test was given to examine the impact of MALQ on their listening comprehension for the short story. Upon completion of the Post-test, they were asked to complete the MALQ to re-examine their level of metacognitive awareness for listening comprehension. A week after the post-test, students completed their listening $\log$ in the form of LIRA (Listen-Interact-Reflect-Act/Answer) by writing a paragraph of 150 words, based on the given prompts.

\section{ANALYSIS OF DATA}

Both Pre-test and Post-test correct scores were compared and analyzed. In addition, the overall responses to the Likert Scales for MALQ (Pre and Post-tests) were compared and analyzed to identify the levels of Metacognitive Awareness for completing the listening comprehension task. Then, the detailed percentage of the Likert Scale responses of each MALQ categories (problem solving, planning and evaluation, mental translation, person knowledge, and directed attention) were compared and analyzed to examine the influence of Metacognitive awareness on their listening comprehension scores.

\section{FINDINGS}

The findings are shown in the two figures below. Figure 1 shows the results for MCQ test scores and Figure 2 shows the survey responses for MALQ strategies.

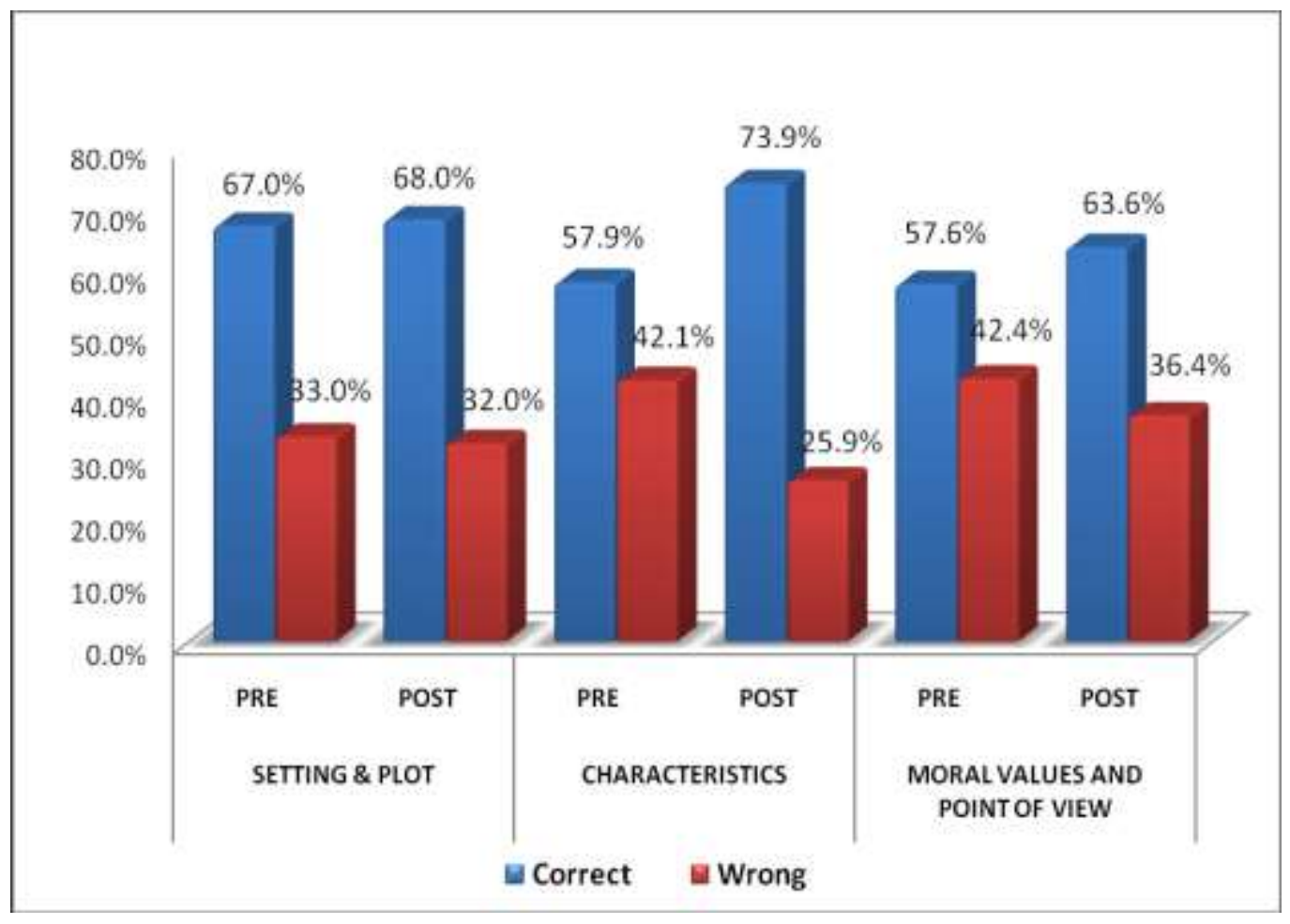

Figure 2: MCQ - Pre and Post Tests 
In Figure 2, the percentage of correct answers for test scores are shown in blue vertical bars and the percentage of wrong answers are shown as red vertical bars. Overall, the findings show an increase in the percentage of correct answers for the listening comprehension task, based on the MCQ given. The MCQ for pre and post tests are categorized into three aspects: setting and plot; characteristics; and also moral values and point of view. For setting and plot, the increase in the percentage of correct answers is from 67\% (Pre Test) to 68\% (Post Test). As for characteristics, the increase is from $57.9 \%$ to $73.9 \%$. Additionally, the increase in percentage for moral values and point of view is from $57.6 \%$ to $63.3 \%$. The increases in the percentage from pre-test to post-test indicate that the participants responded positively to the MALQ strategies. The MALQ strategies were not applied at the pre-test but were employed during the post-test. The findings reveal that the MALQ strategies helped the participants to improve their test scores. Therefore, the MALQ strategies have positive influence on the MCQ test scores.

In Figure 3, the blue vertical bars indicate the percentages of Strongly Agree, Partly Agree and Agree. The red vertical bars indicate the percentages for Strongly Disagree, Disagree and Slightly Disagree.

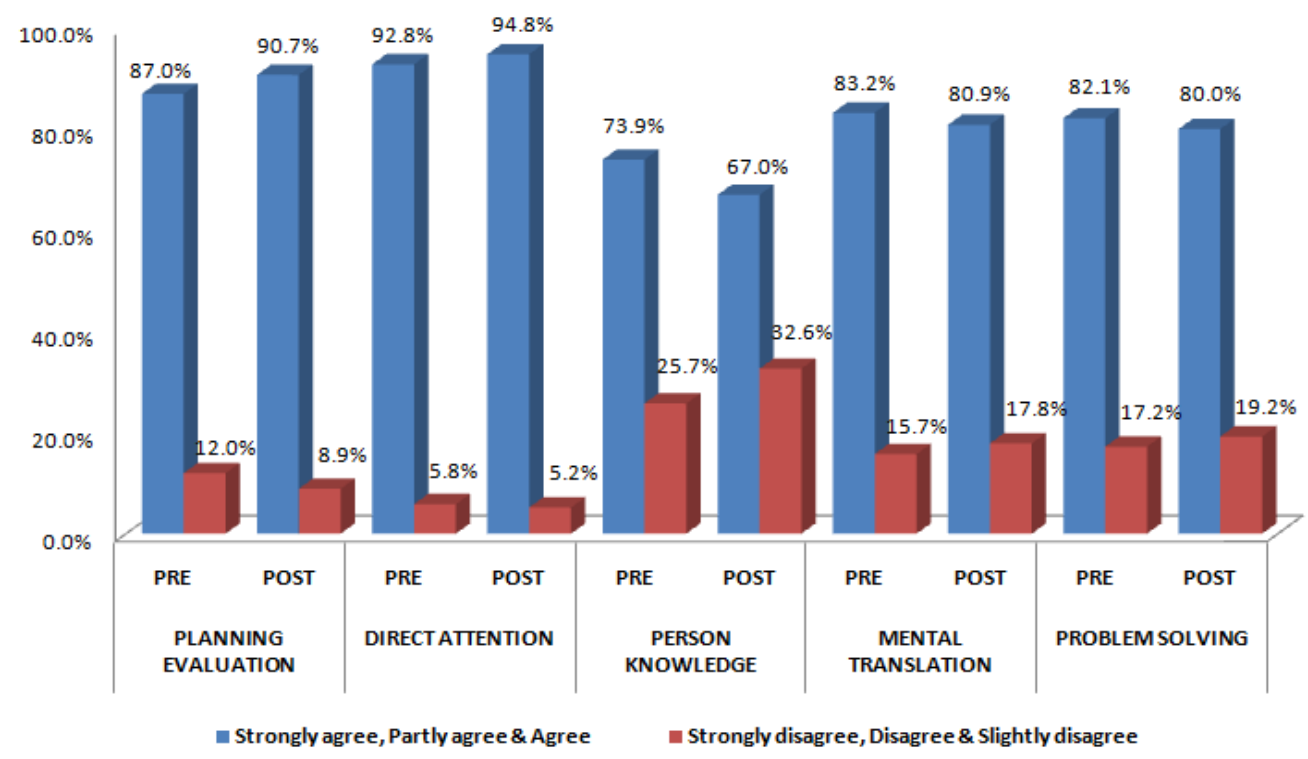

Figure 3: MALQ - Pre and Post Survey

Based on Figure 3 above, the percentages of strongly agree, partly agree and agree are positively reflected in the two MALQ strategies for planning and evaluation (from $87.0 \%$ to $90.7 \%$ ) and direct attention (from 92.8\% to 94.8\%). The positive increase indicates that the participants have better awareness towards the MALQ strategies related to planning and evaluation, as well as, direct attention. These increased levels of awareness contributed to the respondents' understanding of the story 'The last leaf'. Therefore, the awareness strategies have encouraging influence on their MCQ test scores, as shown in Figure 1.The negative statements for 'Person Knowledge', 'Mental Translation' and 'Problem Solving' indicate that the increase in percentages for strongly disagree, disagree and slightly disagree have positive connotations on the findings for MALQ strategies. For example: the increase from 
$25.7 \%$ to $32.6 \%$ for 'Person Knowledge', $15.7 \%$ to $17.8 \%$ for 'Mental Translation', and $17.2 \%$ to $19.2 \%$ for 'Problem Solving' show that the respondents are positively influenced by the strategies employed. Hence, their test scores are positively impacted by their awareness strategies.

\section{CONCLUSION}

The findings reveal that metacognitive strategy awareness has a positive effect on students' test scores, which is consistent with the findings by Vandergrift, Goh, Mareschal and Tafaghodtari (2006), Rahimi and Katal (2012) and Nair (2014). By having certain levels of awareness, students can conduct self-learning and become more competent in their listening tasks. According to Vandergrift (2002), metacognitive strategies provide language learners with the knowledge and tools to understand authentic texts outside of the classroom. The increase in the students' metacognitive awareness levels allow them to insightfully deal with listening tasks, purposefully plan for appropriate strategies and carefully monitor their own learning. Given the above findings, it would be useful for ESL teachers to enhance the use of strategies among students, such as planning and evaluation, direct attention and personal knowledge. In light of the results of this study, metacognitive strategies awareness can be improvised for classroom instructions. Further research is necessary to study how metacognitive strategies affect the students' listening performance, as well as, to conduct interventions that will encourage metacognitive awareness.

\section{REFERENCES}

Abdullah Coskun. (2010). The effect of metacognitive strategy training on the listening performance of beginner students. Novitas-ROYAL, 4(1), 35-50.

Ferris, D., \& Tagg, T. (1996). Academic listening/speaking tasks for ESL students: Problems, suggestions, and implications. TESOL Quarterly, 30(2), 297-320.

Flavell, J. H. (1976). Metacognitive aspects of problem solving. In L. Resnick, (Ed.), The Nature of Intelligence (pp. 231-235). Hillsdale, NJ: Lawrence Erlbaum Associates.

Chang, C. W. (2013). Metacognitive awareness in English listening: A study of Taiwanese nonEnglish majors. Journal of National Natural Science and Technology, 31(3), 75-90.

Goh, C. C. M. (2002). Exploring listening comprehension tactics and their interaction patterns. System, 30(2), 185-206.

Goh, C. C. M. (2000). A cognitive perspective on language learners' listening comprehension problems. System, 28(1), 55-75.

Goh, C. C. M. (1997). Metacognitive awareness and Second Language Listeners. ELT Journal, 51(4), 361-369.

Hargie, O. (2011). Skilled interpersonal interaction: Research, theory, and practice. London: Routledge.

Huang J., \& Finn, A. (2009). Academic listening tests for ESOL students: Availability, concerns, and solutions. International Journal of Applied Educational Studies, 6(1), 46-55.

Nair, S., Koo, Y. L., \& Abu Bakar, K. (2014). Exploring the listening processes of PreUniversity ESL students. Procedia - Social and Behavioural Sciences, 118, 475-482.

O'Malley, J. M., \& Chamot, A.U. (1990). Learning strategies in Second Language Acquisition. Cambridge: Cambridge University Press. 
Osada, N. (2001). What strategy do less proficient learners employ in listening comprehension? A reappraisal of bottom-up and top-down processing. Journal of the Pan- Pacific Association of Applied Linguistics, 5(1), 73-90.

Oxford, R. L. (1993). Research update on teaching L2 listening. System, 21 (2), 205-211.

Parviz Birjandi., \& Amir Hossein Rahimi. (2012). The effect of metacognitive strategy instruction on the listening performance of EFL Students. International Journal of Linguistics, 4(2), 495-517.

Rahimi, M., \& Katal, M. (2012). Metacognitive strategies awareness in learning English as a foreign language: A comparison between university and high school students. ProcediaSocial and Behavioural Sciences, 31, 82-89.

Rahimirad, M., \&Moini, M. R. (2015).The challenges of listening to academic lectures for EAP learners and the impact of metacognition on academic lecture listening comprehension. SAGE Open, 5(2), 1-9. DOI: 10.1177/2158244015590609

Selamat, S., \& Sidhu, G. K. (2011). Student perceptions of metacognitive strategy use in lecture listening comprehension. Language Education in Asia, 2(2), 185-195.

Thompson, I., \& Rubin, J. (1996). Can strategy instruction improve listening comprehension? Foreign Language Annals, 29(3), 331-342.

Vandergrift, L. (1999). Facilitating second language listening comprehension: Acquiring successful strategies. ELT Journal, 53(3), 168-176.

Vandergrift, L. (1997). The strategies of second language (French) listeners: A descriptive study. Foreign Language Annals, 30(3), 387-409.

Vandergrift, L. (2002). It was nice to see that our predictions were right: Developing metacognition in L2 listening comprehension. The Canadian Modern Language Review, 58(4), 555-575. http://dx.doi.org/10.3138/cmlr.58.4.555

Vandergrift, L. (2003). From prediction through reflection: Guiding students through the process of L2 listening. Canadian Modern Language Review, 59(3), 425-440. Retrieved from http://dx.doi.org/10.3138/cmlr.59.3.425

Vandergrift, L., \& Tafaghodtari, M. (2010). Teaching L2 learners how to listen does make a difference: An empirical study. Language Learning, 60(2), 470-497. Retrieved from http://dx.doi.org/10.1111/j.1467-9922.2009.00559.x

Vandergrift, L., Goh, C. C. M., Mareschal, C. J., \& Tafaghodtari, M. Z. (2006). The metacognitive awareness listening questionnaire: Development and validation. Language Learning, 56(3), 431-462. 